\title{
Investigation of effects of layer positions on mechanical buckling behavior of axially layered functionally graded beams
}

\author{
Eksenel yönde tabakalı fonksiyonel derecelendirilmiş kirişlerin mekanik \\ burkulma davranışı üzerinde tabaka pozisyonlarının etkilerinin \\ incelenmesi
}

\author{
Savaş EVRAN* iD \\ Dep. of Machine and Metal Tech. Vocational School of Canakkale Tech. Sciences, Canakkale Onsekiz Mart Univ. Canakkale, Turkey.
} sevran@comu.edu.tr

Received/Geliş Tarihi: 01.06.2018, Accepted/Kabul Tarihi: 24.09.2018

* Corresponding author/Yazișılan Yazar

doi: $10.5505 /$ pajes.2018.00243

Research Article/Arastırma Makalesi

\begin{abstract}
The aim of this research is to examine the mechanical buckling behavior of multi-layered functionally graded beams in the axial direction. Numerical buckling analyses were performed using finite element software called ANSYS. Each beam configuration is suggested to be three layers prepared using various percent volume fractions of Zirconia $\left(\mathrm{ZrO}_{2}\right)$ and Aluminum (Al) materials. The levels of layers and layer positions of the beams were evaluated according to Taguchi's $L_{9}$ $\left(3^{3}\right)$ orthogonal array technique. Layers were determined as control factor and so nine numerical analyses were performed under clampedclamped boundary conditions. The first mode shapes of the axially layered functionally graded beams were demonstrated in order to detect the most affected layers as visually. Analysis of signal-to-noise ratio was applied to obtain the optimum levels of layers. Analysis of Variance (ANOVA) was employed to solve the layers with significant impacts and their percent contributions on numerical results. The maximum buckling load was determined using various positions of layers with the optimum levels obtained based on Taguchi methodology.
\end{abstract}

Keywords: Functionally graded materials, Beam, Buckling, Finite element method

\section{Introduction}

Beams and columns are significant structure members in various applications of engineering areas such as aerospace, automotive and marine etc. and they are generally made from different material types such as isotropic, composite and functionally graded materials (FGMs). FGM is useful and widely accepted in mechanical engineering and so it is possible to find a wide range of studies containing buckling analysis based on FGMs. In the literature, Li et al. [1] presented the bending, buckling and vibration analyses of the beams composed of functionally graded materials with ceramic and metal systems in axially direction according to nonlocal strain gradient theory. Kahya and Turan [2] suggested a model based on finite element to perform the buckling and free vibration analyses of the FG beams according to the first order shear deformation theory. Trinh et al. [3] proposed the analytical method in order to perform the buckling and vibration analyses of FG beams subjected to mechanical and thermal loads according to different boundary conditions. Vo et al. [4] reported a model based on finite element to carry out the buckling and vibration behavior of sandwich beams with functionally graded materials and they used a refined shear deformation theory for their
Öz

Bu araștırmanın amacl eksenel yönde çoklu tabakalı fonksiyonel derecelendirilmiş kirişlerin mekanik burkulma davranışlarını incelemektir. Sayısal burkulma analizleri ANSYS olarak bilinen sonlu elemanlar yazılımı kullanılarak gerçekleştirilmiştir. Her kiriş konfigürasyonu Zirkonyum $\left(\mathrm{ZrO}_{2}\right)$ ve Alüminyum (Al) malzemelerinin değişik yüzde hacim fraksiyonları kullanılarak hazırlanmış üç tabaka olarak önerilmiștir. Tabaka seviyeleri ve kirişlerin tabaka pozisyonlar Taguchi $L_{9}\left(3^{3}\right)$ ortogonal dizi tekniğine göre incelenmiștir. Tabakalar kontrol faktörleri olarak değerlendirildi ve böylece dokuz sayısal analiz tutulu-tutulu sinır șartları altında gerçekleștirildi. Görsel olarak en çok etkilenen tabakaları tespit etmek için eksenel yönde tabakalı olarak fonksiyonel derecelendirilirmiș kirișlerin birinci mod șekilleri gösterildi. Tabakaların optimum seviyelerini elde edebilmek için sinyal-gürültü oran analizi kullanıld. Sayısal sonuçlar üzerinde önemli etkilere sahip tabakalar ve onların yüzde katkı oranlarını çözmek için Varyans Analizi (ANOVA) uygulandı. En yüksek burkulma yükü Taguchi metodolojisine bağlı elde edilen optimum seviyeli tabakaların değișik pozisyonları kullanılarak karar verildi.

Anahtar kelimeler: Fonksiyonel derecelendirilmiș malzemeler, Kiriș, Burkulma, Sonlu elemanlar metodu

study. Şimşek [5] evaluated the buckling characteristics of FG Timoshenko beams in axial and thickness directions for two dimensions under various boundary conditions. Huang et al. [6] presented a research consisting of buckling characteristics of beams with axially functionally graded and non-uniform and they used Timoshenko beam theory. As can be seen from the literature survey mentioned, there are several studies consisting of buckling analyses of the FG beams. In addition, there are various method for buckling analysis, such as localized differential quadrature method [7] semi-inverse method [8], functional perturbation method [9], variational iteration method [10], homotopy perturbation method [11], integral-equation approach [12], and exact dynamic stiffness method [13] etc. In the study presented, the mechanical buckling behavior of multi-layered functionally graded beams in the axial direction was investigated under clamped-clamped (C-C) boundary conditions. The layer positions were conducted using Taguchi's L9 orthogonal array in order to carry out the optimum levels of layers on the buckling analyses. Finite element software as named ANSYS V13 Parametric Design Language (Mechanical APDL) was used for numerical analyses. In addition, the effects of layer positions and mechanical 
properties of layers on buckling characteristic of axially layered functionally graded beams were evaluated.

\section{Materials and methods}

In engineering areas, the beams are generally manufactured using different materials such as metal and ceramic. In this study, the beams were designed using different percent volume fractions of metal (Aluminium) and ceramic (Zirconia) material in order to investigate the effects of layer positions and mechanical properties of layers on buckling behaviour of axially layered FG beams. Mechanical properties of FGM components, such as Young's modulus and Poisson's ratio, were given in Table 1.

Table 1: Mechanical properties of FGM components [14].

\begin{tabular}{cccc}
\hline Material & Type of & \multicolumn{2}{c}{ Mechanical Properties } \\
\cline { 3 - 4 } & Material & $\begin{array}{c}\text { Young's module } \\
(\mathrm{GPa})\end{array}$ & $\begin{array}{c}\text { Poisson's } \\
\text { ratio }\end{array}$ \\
\hline Aluminum & Metal & 70 & 0.3 \\
Zirconia & Ceramic & 151 & 0.3 \\
\hline
\end{tabular}

The Poisson's ratio for each material is constant and is used to be 0.3 . The layer positions of the axially layered FG beams are employed using L9 orthogonal array with three factors and three levels each based on Taguchi Method and the layers are claimed to be control factors. The control factors and the levels are listed in Table 2.

Table 2: Control factors and levels.

\begin{tabular}{ccccc}
\hline Control Factors & Symbol & \multicolumn{3}{c}{ Levels } \\
\hline Bottom Layer & BL & $(\mathrm{BL})_{1}$ & $(\mathrm{BL})_{2}$ & $(\mathrm{BL})_{3}$ \\
Middle Layer & ML & $(\mathrm{ML})_{1}$ & $(\mathrm{ML})_{2}$ & $(\mathrm{ML})_{3}$ \\
Top Layer & TL & $(\mathrm{TL})_{1}$ & $(\mathrm{TL})_{2}$ & $(\mathrm{TL})_{3}$ \\
\hline
\end{tabular}

The axially layered functionally graded beams consist of three different layers designed from Zirconia/Aluminum systems and so the mechanical property of each layer is different from each other. The effective mechanical properties $\left(\mathrm{P}_{\mathrm{ef}}\right)$ of the layers of beams can be represented as Equation 1 [15].

$$
\mathrm{P}_{\mathrm{ef}}=\sum_{\mathrm{i}=1} \mathrm{P}_{\mathrm{i}} \mathrm{V}_{\mathrm{f}_{\mathrm{i}}}
$$

where, $P_{i}$ and $V_{f_{i}}$ are claimed to be the mechanical properties and volume fraction based on the constituent material $i$ respectively. The sum of the volume fractions for all the constituent materials are written to be one as demonstrated in Equation 2 [15].

$$
\sum_{i=1} V_{f_{i}}=1
$$

The change of the percent volume fractions of ceramic materials in layers are considered based on 3\%. In order to obtain the maximum results for critical buckling load $\left(\mathrm{F}_{\mathrm{cr}}\right)$ of the axially layered functionally graded beams, the numerical results computed based on ANSYS software are observed using Minitab 15 software based on "higher is better" quality characteristic as noted in Equation 3 [16].

$$
(\mathrm{S} / \mathrm{N})_{\mathrm{HB}} \text { for } F_{c r}=-10 \cdot \log \left(\mathrm{n}^{-1} \sum_{\mathrm{i}=1}^{\mathrm{n}}\left(\mathrm{y}_{\mathrm{i}}^{2}\right)^{-1}\right)
$$

where, $\mathrm{n}$ points out the number of analysis for buckling behavior in a trial and $y_{i}$ explains the determined ith data.

\section{Numerical approach}

Numerical first mode buckling analyses of the axially layered FG beams were evaluated using finite element software ANSYS APDL. The layers of the beams were modelled using different percent volume fractions of ceramic and metal materials in finite element software. The material properties of the each beam are considered to vary along the axial direction based on three layers. In analyses, BEAM189 element type was used for analyses. The element type includes Timoshenko beam theory which having shear-deformation effects and it is quadratic 3 -node beam element in three dimensions [17]. The crosssectional area and length of each layer is assumed to be $15 \times 15$ $\mathrm{mm}^{2}$ and $100 \mathrm{~mm}$ respectively. The length of the axially layered FG beams is claimed to be $300 \mathrm{~mm}$. Mesh operation for each layer was performed using NDIV (no. of element divisions) based on 100 value. The beams were analyzed under clampedclamped boundary conditions. Thus $\mathrm{UX}=\mathrm{UY}=\mathrm{UZ}=\mathrm{ROTX}=$ ROTZ=ROTY $=0$ for bottom end and $\mathrm{UX}=\mathrm{UZ}=\mathrm{ROTX}=\mathrm{ROTZ}=$ ROTY $=0$, UY $\neq 0$ for top end. The beams were designed using three layers and the beam configuration designed was demonstrated in Figure 1.

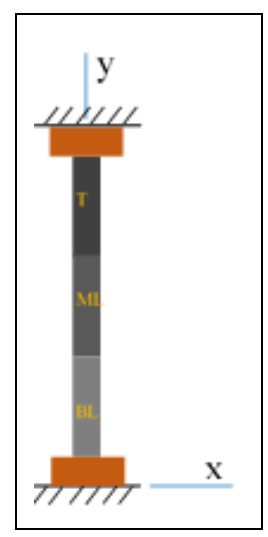

Figure 1: Axially layered FG beam for C-C boundary conditions.

\section{Critical buckling results and discussions}

In the study, numerical design for first mode buckling analyses of the axially layered FG beams was achieved based on Taguchi's L9 orthogonal array. $\mathrm{S} / \mathrm{N}$ ratio results of raw data for buckling analyses were calculated using Minitab 15 software. The critical buckling results for first mode and their $\mathrm{S} / \mathrm{N}$ ratio data were illustrated in Table 3. Numerical results and the first mode shapes for axially layered FG beams were demonstrated in Figure 2. According to Figure 2, the maximum buckling behavior of the beams was performed in the middle layers whereas the minimum buckling behavior were obtained in end layers.

Table 3: Numerical design using L9 orthogonal array.

\begin{tabular}{clllll}
\hline \multirow{2}{*}{$\begin{array}{l}\text { Analysis } \\
\text { No. }\end{array}$} & \multicolumn{2}{l}{ Layers and Levels } & Results & \\
\cline { 2 - 6 } & BL & ML & TL & $\mathrm{F}_{\text {cr }}(\mathrm{N})$ & $\begin{array}{l}\text { S/N } \\
\text { (dB) }\end{array}$ \\
\hline 1 & $(\mathrm{BL})_{1}$ & $(\mathrm{ML})_{1}$ & $(\mathrm{TL})_{1}$ & 143469 & 103.135 \\
2 & $(\mathrm{BL})_{1}$ & $(\mathrm{ML})_{2}$ & $(\mathrm{TL})_{2}$ & 146527 & 103.318 \\
3 & $(\mathrm{BL})_{1}$ & $(\mathrm{ML})_{3}$ & $(\mathrm{TL})_{3}$ & 149546 & 103.495 \\
4 & $(\mathrm{BL})_{2}$ & $(\mathrm{ML})_{1}$ & $(\mathrm{TL})_{2}$ & 145834 & 103.277 \\
5 & $(\mathrm{BL})_{2}$ & $(\mathrm{ML})_{2}$ & $(\mathrm{TL})_{3}$ & 148918 & 103.459 \\
6 & $(\mathrm{BL})_{2}$ & $(\mathrm{ML})_{3}$ & $(\mathrm{TL})_{1}$ & 148788 & 103.451 \\
7 & $(\mathrm{BL})_{3}$ & $(\mathrm{ML})_{1}$ & $(\mathrm{TL})_{3}$ & 148162 & 103.415 \\
8 & $(\mathrm{BL})_{3}$ & $(\mathrm{ML})_{2}$ & $(\mathrm{TL})_{1}$ & 148086 & 103.410 \\
9 & $(\mathrm{BL})_{3}$ & $(\mathrm{ML})_{3}$ & $(\mathrm{TL})_{2}$ & 151193 & 103.591 \\
\hline \multicolumn{7}{c}{ Overall Mean $(\overline{\mathrm{T}})$} & & & 147835.89 & \\
\hline
\end{tabular}




\subsection{Investigation of layers with optimum levels}

Average values of raw and $\mathrm{S} / \mathrm{N}$ ratio data at each levels of each control factor were needed in order to achieve the optimal conditions. Thus, the numerical data obtained by using finite element software ANSYS were analyzed based on Taguchi's L9 orthogonal array in order to achieve the optimum levels of layers on the first mode buckling loads of the axially layered FG beams for the maximum result. Average data of raw results computed according to each level of each layer and their S/N ratio results were calculated using Minitab 15 software and so these results were tabulated in Table 4.

Table 4 shows that the optimum levels of layers of the axially layered FG beams for the maximum critical buckling load were carried out to be the third levels of layers according to "Higher is Better" quality characteristic.

\subsection{Effect of \% volume fractions of materials in layers}

The layered FG beams in axial direction were prepared using various layers consisting of different mechanical properties. The layers were designed according to various percent volume fractions of the ceramic and metal materials and so the layers with different characteristics from each other were designed. The average data of $\mathrm{S} / \mathrm{N}$ ratio values based on each level of each layer were used in order to detect the influence of layers on the critical buckling load analysis of the beams under C-C boundary conditions. The main effects plot of layers according to $\mathrm{S} / \mathrm{N}$ ratio values were illustrated in Figure 3.

As can be obviously seen from Figure 3, the increase of the percent ceramic volume fractions in layers causes the increase the critical buckling loads whereas the increase of the percent metal volume fractions provides the decrease of responses and so the maximum critical buckling load can be obtained using the beams with layers made from the high \% ceramic volume fractions.

\subsection{Analysis of Variance}

Analysis of Variance (ANOVA) was developed in order to achieve the layers with significant impacts and the percent effects of the layers on the performance measure. Analyses at $95 \%$ confidence level were performed using raw data of the critical buckling loads. The results obtained based on ANOVA are presented in Table 5.

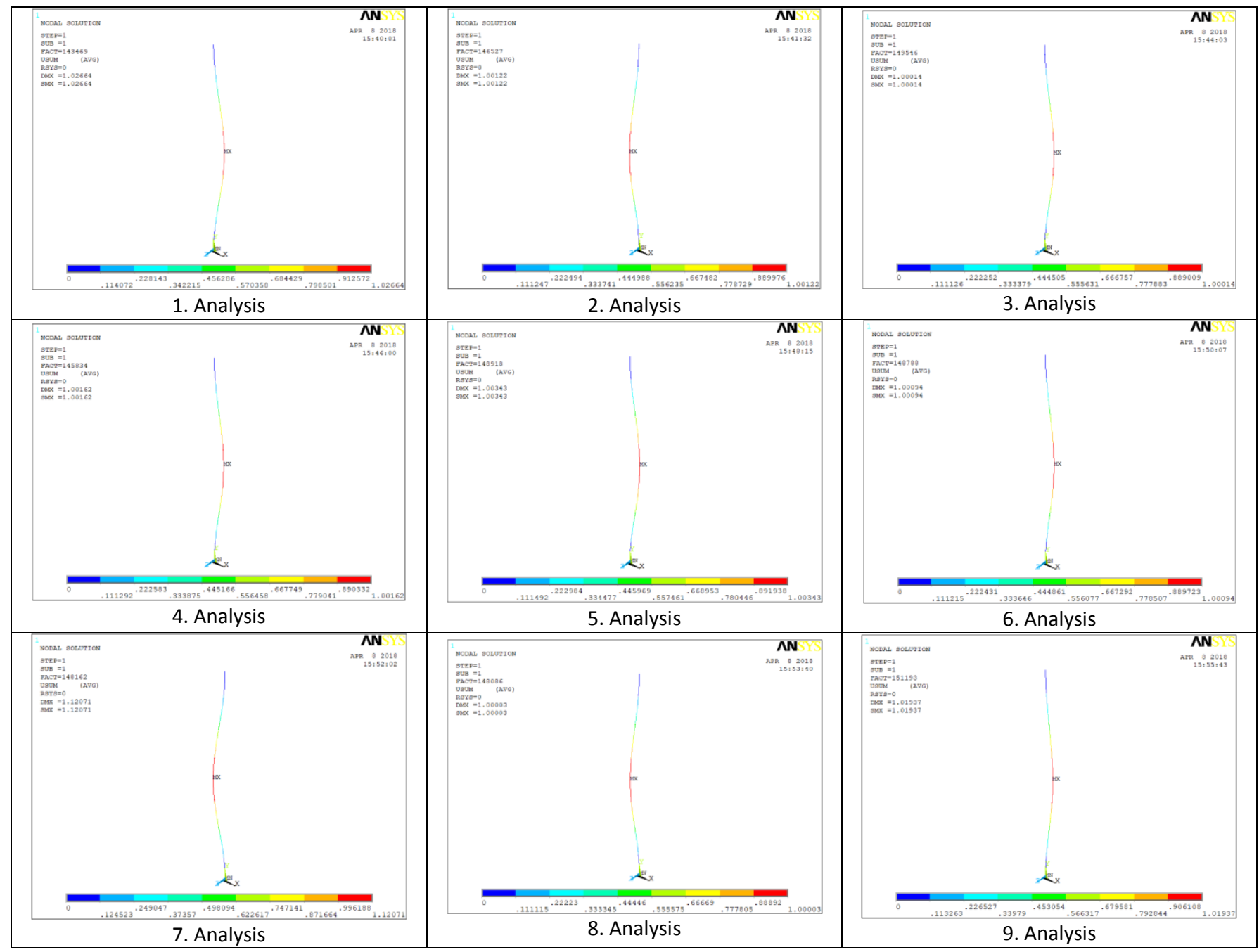

Figure 2: Numerical data and the first mode shapes of the beams based on L9 orthogonal array. 


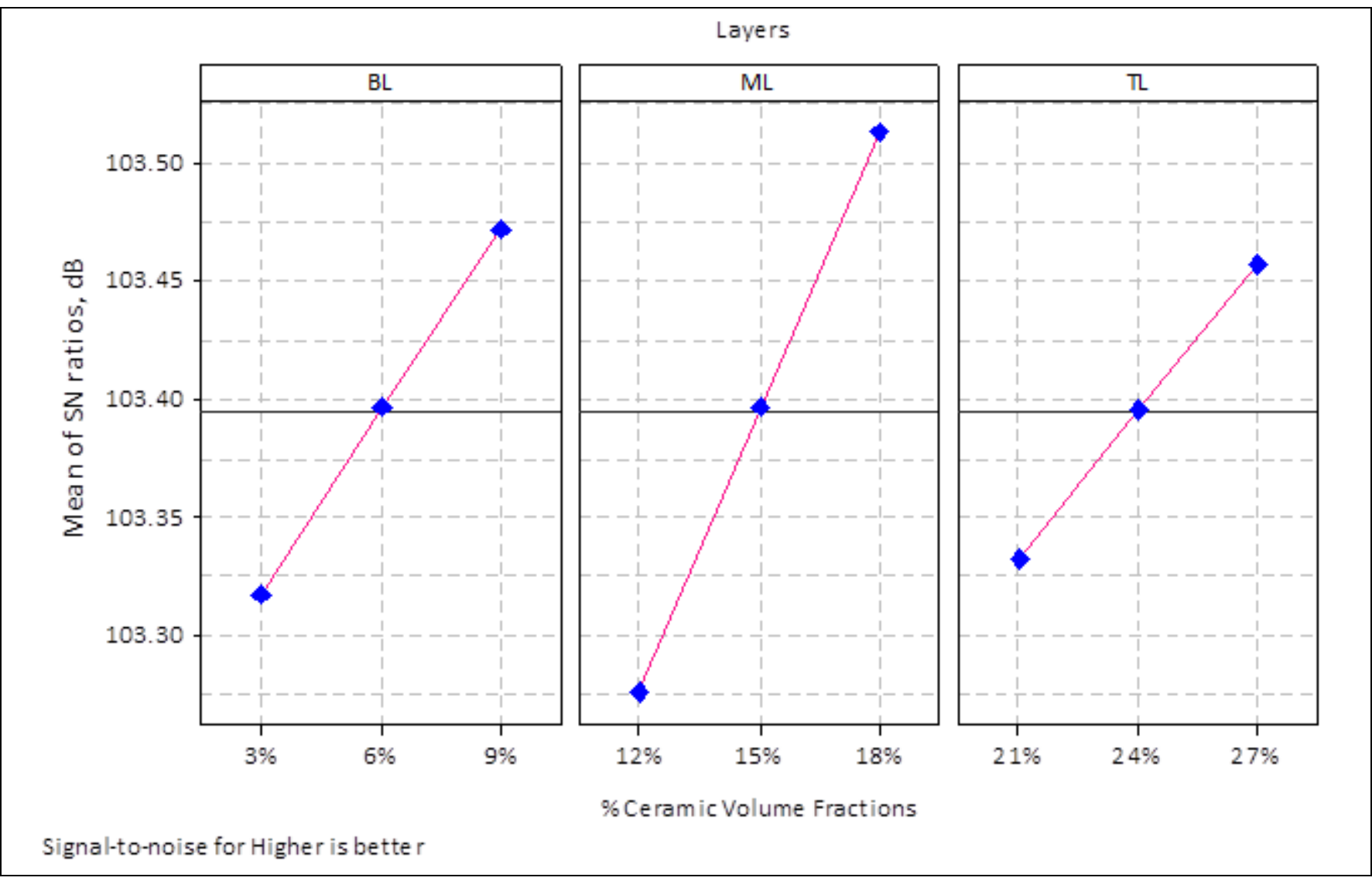

Figure 3: Main effects plot of layers for $\mathrm{S} / \mathrm{N}$ ratio data.

Table 4: Responses table for critical buckling behavior.

\begin{tabular}{|c|c|c|c|c|c|c|}
\hline \multirow{2}{*}{ Level } & \multicolumn{2}{|c|}{ Signal to Noise Ratios in $\mathrm{dB}$} & \multicolumn{3}{|c|}{ Means in $\mathrm{N}$} & \multirow[b]{2}{*}{ TL } \\
\hline & BL & ML & $\mathrm{TL}$ & BL & ML & \\
\hline 1 & 103.3 & 103.3 & 103.3 & 146514 & 145822 & 146781 \\
\hline 2 & 103.4 & 103.4 & 103.4 & 147847 & 147844 & 147851 \\
\hline 3 & 103.5 & 103.5 & 103.5 & 149147 & 149842 & 148875 \\
\hline Delta & 0.2 & 0.2 & 0.1 & 2633 & 4021 & 2094 \\
\hline Rank & 2 & 1 & 3 & 2 & 1 & 3 \\
\hline
\end{tabular}

Table 5: ANOVA results for raw data.

\begin{tabular}{clllllll}
\hline Source & DF & Seq SS & Adj SS & Adj MS & F & P & \% Influence \\
\hline BL & 2 & 10399556 & 10399556 & 5199778 & 3944.87 & 0 & 25.22 \\
ML & 2 & 24248913 & 24248913 & 12124456 & 9198.36 & 0 & 58.81 \\
TL & 2 & 6580422 & 6580422 & 3290211 & 2496.16 & 0 & 15.96 \\
Error & 2 & 2636 & 2636 & 1318 & & 0.01 \\
Total & 8 & 41231527 & & & & 100 \\
\hline
\end{tabular}

$S=36.3058, \mathrm{R}-\mathrm{Sq}=99.99 \%, \mathrm{R}-\mathrm{Sq}(\mathrm{adj})=99.97 \%$. 
In the Table 5, DF, SS, MS represent the symbols such as degrees of freedom, sum of squares, variance respectively. According to ANOVA data, ML with 58.81\% influence and BL with $25.22 \%$ influence, and TL with $15.96 \%$ influence were carried out to be the major factors affecting buckling behavior of the beams, respectively. The error value of ANOVA was found to be $0.01 \%$. In addition, the layers exert significant impacts on the critical buckling loads depending on $\mathrm{P}<0.05$ value.

\subsection{Estimation of optimum critical buckling load}

In order to estimate the optimum critical buckling load for first mode of axially layered FG beams, the significant layers determined based on ANOVA at $95 \%$ confidence level $(\mathrm{P}<0.05)$ were used. The estimated mean of the optimum critical buckling load can be identified depending to Equation 4 [16].

$$
\mu_{\mathrm{F}_{\mathrm{cr}}}=\overline{\mathrm{BL}_{3}}+\overline{\mathrm{ML}_{3}}+\overline{\mathrm{TL}_{3}}-2 \overline{\mathrm{T}}
$$

where, $\overline{\mathrm{T}}=147835.89 \mathrm{~N}$ is taken to be the overall mean of the first mode critical buckling load for Taguchi L9 orthogonal array. $\overline{\mathrm{BL}_{3}}=149147 \mathrm{~N}, \overline{\mathrm{ML}_{3}}=149842 \mathrm{~N}$, and $\overline{\mathrm{TL}_{3}}=148875 \mathrm{~N}$ represent the average data of the first mode critical buckling loads at third level of bottom layer, middle layer, and top layer respectively and so $\mu_{\mathrm{F}_{\mathrm{cr}}}$ is computed to be $152192.22 \mathrm{~N}$. The $95 \%$ confidence intervals of confirmation analyses ( $\left.\mathrm{CI}_{\mathrm{CA}}\right)$ using Equation 5 [16] and population (CIPOP) using Equation 6 [16] are calculated as follows:

$$
\begin{gathered}
\mathrm{CI}_{\mathrm{CA}}=\left(\mathrm{F}_{\alpha ; 1 ; \mathrm{n}_{2}} \mathrm{~V}_{\mathrm{Er}}\left[\frac{1}{\mathrm{n}_{\mathrm{eff}}}+\frac{1}{\mathrm{R}}\right]\right)^{0.5} \\
\mathrm{CI}_{\mathrm{POP}}=\left(\frac{\mathrm{F}_{\alpha ; 1 ; \mathrm{n}_{2}} \mathrm{~V}_{\mathrm{Er}}}{\mathrm{n}_{\mathrm{eff}}}\right)^{0.5}
\end{gathered}
$$

where, $\alpha$ is risk and it is used to be 0.05 for $95 \%$ confidence level and $\mathrm{n}_{2}=2$ means the error data for degree of freedom in Table 5 and so $\mathrm{F}_{\alpha ; 1 ; \mathrm{n}_{2}}$ is found to be 18.5 from $\mathrm{F}$ values tabulated [16] for $95 \%$ confidence level. $V_{\mathrm{Er}}=1318$ is identified to be error variance in Table $5 . R=1$ is determined to be number of replications for confirmation analyses.

$$
\mathrm{n}_{\mathrm{eff}}=\frac{\mathrm{N}}{\left(1+\mathrm{T}_{\mathrm{DOF}}\right)}
$$

where, $\mathrm{N}$ identifies the total number of numerical analyses and is taken to be $9 . \mathrm{T}_{\mathrm{DOF}}=6$ expresses the number for degree of freedom based on significant control parameters. $\mathrm{n}_{\mathrm{eff}}$ is calculated to be 1.286 and so the predicted confidence interval for confirmation analyses of first mode buckling loads are obtained using following equation [16]:

$$
\text { Mean } \mu_{\mathrm{F}_{\mathrm{cr}}}-\mathrm{CI}_{\mathrm{CA}}<\mu_{\mathrm{F}_{\mathrm{cr}}}<\mathrm{CI}_{\mathrm{CA}}+\text { Mean } \mu_{\sigma_{\mathrm{T}}}
$$

The population according to the $95 \%$ confidence interval is determined using following equation [16]:

$$
\text { Mean } \mu_{\mathrm{F}_{\mathrm{cr}}}-\mathrm{CI}_{\mathrm{POP}}<\mu_{\mathrm{F}_{\mathrm{cr}}}<\mathrm{CI}_{\mathrm{POP}}+\text { Mean } \mu_{\sigma_{\mathrm{T}}}
$$

The $\mathrm{CI}_{\mathrm{CA}}$ and $\mathrm{CI}_{\mathrm{POP}}$ are calculated to be 208.19 and 137.70 respectively. The numerical and the predicted results, confidence intervals for confirmation analyses and population according to the $95 \%$ confidence levels are tabulated in Table 6.

\subsection{Selection of layer arrangements of beams}

In order to detect the maximum critical buckling load based on the first mode, the axially layered FG beams with various layer positions different from each other were designed using layers with the optimum levels. The beam types designed and their numerical buckling results for first mode were presented in Table 7. The increase of percent volume fractions of ceramic contents in the middle layers leads to the increase of the critical buckling loads. Therefore the beam configurations with (BL) $3_{3}$ $(\mathrm{TL})_{3}-(\mathrm{ML})_{3}$ and $(\mathrm{ML})_{3}-(\mathrm{TL})_{3}-(\mathrm{BL})_{3}$ provide the maximum critical buckling load for the first mode. In addition, the minimum critical buckling load based on the first mode are obtained using the beam configurations with (ML) $3-(B L)_{3}-(T L)_{3}$ and $(\mathrm{TL})_{3}-(\mathrm{BL})_{3}-(\mathrm{ML})_{3}$ and these configurations have the middle layers with metal rich according to the layers with the optimum levels.

Table 6: Results for beams made from layers with the optimum levels.

\begin{tabular}{ccc}
\hline No & Type of Configuration & $\mathrm{F}_{\mathrm{cr}}(\mathrm{kN})$ \\
\hline 1 & $(\mathrm{BL})_{3}-(\mathrm{ML})_{3}-(\mathrm{TL})_{3}$ & 152.3 \\
2 & $(\mathrm{BL})_{3}-(\mathrm{TL})_{3}-(\mathrm{ML})_{3}$ & 154.8 \\
3 & $(\mathrm{ML})_{3}-(\mathrm{BL})_{3}-(\mathrm{TL})_{3}$ & 149.7 \\
4 & $(\mathrm{ML})_{3}-(\mathrm{TL})_{3}-(\mathrm{BL})_{3}$ & 154.8 \\
5 & $(\mathrm{TL})_{3}-(\mathrm{BL})_{3}-(\mathrm{ML})_{3}$ & 149.7 \\
6 & $(\mathrm{TL})_{3}-(\mathrm{ML})_{3}-(\mathrm{BL})_{3}$ & 152.3 \\
\hline
\end{tabular}

Numerical results and the mode shapes for the critical buckling load depending on first mode using the optimum levels of the layers are presented in Figure 4 and it can be seen from Figure 4 that the most affected layers are the middle layers.

Table 7: Numerical and predicted results.

\begin{tabular}{cccc}
\hline $\begin{array}{c}\text { Layers with optimum } \\
\text { levels }\end{array}$ & $\begin{array}{c}\text { ANSYS Result } \\
(\mathrm{N})\end{array}$ & $\begin{array}{c}\text { Predicted Results } \\
(\mathrm{N})\end{array}$ & $\begin{array}{c}\text { Predicted Confidence Intervals at 95\% Confidence } \\
\text { Level }\end{array}$ \\
\hline BL3-ML3-TL3 & 152266.00 & 152192.22 & $151984.03<\mu_{F_{c r}}<152400.41$ for CICA \\
\cline { 3 - 3 } & & & $152054.52<\mu_{F_{c r}}<152329.92$ for CIPOP \\
\hline
\end{tabular}




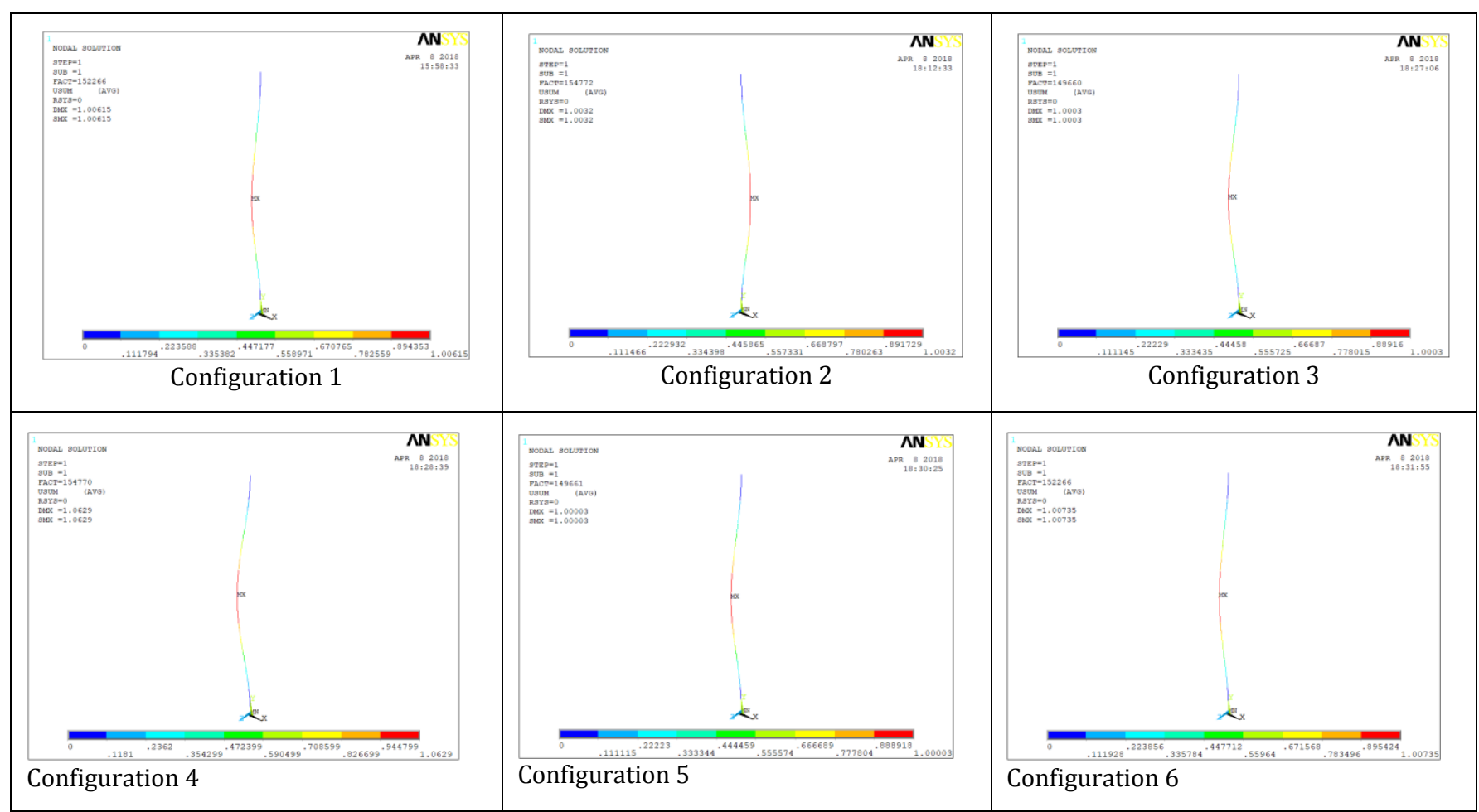

Figure 4: Numerical results and the first mode shapes for beam configurations with optimum layers.

\section{Conclusions}

In the study, the mechanical buckling behavior of the axially layered FG beams designed using different volume fractions of ceramic and metal materials was analyzed based on the finite element software ANSYS V13 Parametric Design Language (Mechanical APDL) under clamped-clamped boundary conditions. The layer arrangements were conducted depending on Taguchi's L9 orthogonal array and the first mode shapes of the axially layered FG beams were illustrated in order to determine the most affected layers as visually. Analysis of signal-to-noise ratio was used in order to investigate the optimum levels of layers. ANOVA was employed in order to achieve the importance levels of layers and the percent effects of layers on the buckling behavior based on the first mode. The various beam configurations were designed using different positions of layers with optimum levels and the beam with optimal layer arrangements was determined for the highest critical buckling load. According to this study, the results summarized are:

1 The critical buckling loads of axially layered FG beams increase with increase of percent volume fractions of the ceramic materials in layers,

2 Overall mean for the first mode critical buckling loads of axially layered FG beams with clamped-clamped boundary conditions is computed to be $147835.89 \mathrm{~N}$ according to Taguchi's L9 orthogonal array,

3 The maximum critical buckling load of axially layered FG beams is found using layers with third levels according to Taguchi Methodology,

4 According to ANOVA based on 95\% confidence level, the layers are control parameters with powerful effects for $\mathrm{P}<0.05$ value. ML with $58.81 \%$ influence and BL with $25.22 \%$ influence, and TL with $15.96 \%$ influence are determined to be the major factors affecting buckling analyses of the beams respectively,

5 The highest critical buckling load for the first mode is obtained using the axially layered FG beams made from middle layers with ceramic-rich according to the optimum layers,

6 Numerical and predicted results corresponding to the optimum conditions are found to be $152266.00 \mathrm{~N}$ and $152192.22 \mathrm{~N}$ respectively,

7 The predicted confidence intervals according to confirmation analyses and population are computed to be $151984.03<\mu_{F_{c r}}<152400.41$ and 152054.52 $<\mu_{F_{c r}}<152329.92$ respectively,

8 The maximum critical buckling load for the first mode is found to be $154.8 \mathrm{kN}$ using the beam configurations with $(\mathrm{BL})_{3}-(\mathrm{TL})_{3}-(\mathrm{ML})_{3}$ and $(\mathrm{ML})_{3}-(\mathrm{TL})_{3}-(\mathrm{BL})_{3}$.

\section{References}

[1] Li X, Li L, Hu Y, Ding Z, Deng W. "Bending, buckling and vibration of axially functionally graded beams based on nonlocal strain gradient theory". Composite Structures, 165, 250-265, 2017.

[2] Kahya V, Turan M. "Finite element model for vibration and buckling of functionally graded beams based on the firstorder shear deformation theory". Composites Part B: Engineering, 109, 108-115, 2017.

[3] Trinh LC, Vo TP, Thai H-T, Nguyen TK. "An analytical method for the vibration and buckling of functionally graded beams under mechanical and thermal loads". Composites Part B: Engineering, 100, 152-163, 2016. 
[4] Vo TP, Thai HT, Nguyen T-K, Maheri A, Lee J. "Finite element model for vibration and buckling of functionally graded sandwich beams based on a refined shear deformation theory". Engineering Structures, 64, 12-22, 2014.

[5] Şimşek M. "Buckling of timoshenko beams composed of two-dimensional functionally graded material (2D-FGM) having different boundary conditions". Composite Structures, 149, 304-314, 2016.

[6] Huang Y, Zhang M, Rong H. "Buckling analysis of axially functionally graded and non-uniform beams based on timoshenko theory". Acta Mechanica Solida Sinica, 29(2), 200-207, 2016.

[7] Yilmaz Y, Girgin Z, Evran S. "Buckling analyses of axially functionally graded nonuniform columns with elastic restraint using a localized differential quadrature method". Mathematical Problems in Engineering, 2013, 1-12, 2013.

[8] Aydogdu M. "Semi-Inverse method for vibration and buckling of axially functionally graded beams". Journal of Reinforced Plastics and Composites, 27(7), 683-691, 2008.

[9] Totry EM, Altus E, Proskura A. "Buckling of non-uniform beams by a direct functional perturbation method". Probabilistic Engineering Mechanics, 22(1), 88-99, 2007.

[10] Coşkun SB, Atay MT. "Determination of critical buckling load for elastic columns of constant and variable cross-sections using variational iteration method". Computers \& Mathematics with Applications, 58(11-12), 2260-2266, 2009.
[11] Coşkun S. "Determination of critical buckling loads for euler columns of variable flexural stiffness with a continuous elastic restraint using homotopy perturbation method". International Journal of Nonlinear Sciences and Numerical Simulation, 10(2), 191-198, 2009.

[12] Arbabi F, Li F. "Buckling of variable cross-section columns: integral-equation approach". Journal of Structural Engineering, 117(8), 2426-2441, 1991.

[13] Yuan S, Ye K, Xiao C, Williams FW, Kennedy D. "Exact dynamic stiffness method for non-uniform Timoshenko beam vibrations and bernoulli-euler column buckling". Journal of Sound and Vibration, 303(3-5), 526-537, 2007.

[14] Bahar U, Metin A. "Three-dimensional vibration analyses of functionally graded plates under various boundary conditions". Journal of Reinforced Plastics and Composites, 26(18), 1847-1863, 2007.

[15] Shen HS. Functionally Graded Materials: Nonlinear Analysis of Plates and Shells. Boca Raton, New York, London, CRC Press, 2009.

[16] Ross PJ. Taguchi Techniques for Quality Engineering. $2^{\text {nd }}$ ed. New York, USA, McGraw-Hill International Editions 1996.

[17] ANSYS Help, Version 13. 